\section{Biology and Control of Bacterial Leaf Blight of Cornus mas}

\author{
M.T. Mmbaga ${ }^{1}$ and E.C. Nnodu \\ Tennessee State University, Otis L. Floyd Nursery Research Center, McMinnville, \\ TN 37110

\section{Additional index words. dogwood, Pseudomonas syringae, fungicide/bactericide}

\begin{abstract}
Cornelian cherry (Cornus mas L.) has been free of disease and pest problems until recently when a bacterial leaf blight caused by Pseudomonas syringae was reported. Since its first observation in middle Tennessee in 1999, the disease has become endemic in the nursery where it was first discovered. The objective of this study was to assess the disease, evaluate factors that favor disease development, and develop disease management strategies. Cool temperatures of 20 to $24^{\circ} \mathrm{C}$ (day) and 10 to $15^{\circ} \mathrm{C}$ (night) were most favorable to the disease and young leaves were highly susceptible while mature leaves were resistant to infection. Leaf wounding increased the susceptibility of leaves and mature leaves developed infection at $28{ }^{\circ} \mathrm{C}$, temperature at which nonwounded leaves were completely resistant to infection. Results from this study also showed that plant propagation from seemingly healthy branches of infected plants may have perpetuated the disease at the nursery. Six chemicals-Phyton-27 (copper sulfate), Camelot (copper salt of fatty acids), Agri-Mycin 17 (streptomycin), Kocide 101 (copper hydroxide), Basicop (elemental copper 53\%), and, Bordeaux mixture (cupric sulfate + lime) were evaluated for disease control. Phyton-27, and Agri-Mycin - were most effective and reduced disease severity to $10 \%$ of foliage showing disease symptoms. Information from this study will be useful in designing effective disease management strategies.
\end{abstract}

Cornelian cherry (Cornus mas L.), a native to eastern Europe and western Asia, has demonstrated longevity and adaptability where it has been grown with no apparent disease and pest problems. It is credited as an enduring dogwood cultivated since the ancient time; it has brought beauty and flavor to the landscapes (Dirr, 1990). In North America, it is used solely as a landscape ornamental, as a specimen tree or shrub or as a large sheared hedge. Cornelian cherry is one of the earliest blooming spring flowering trees and shrubs, with flowers emerging before the leaves. In some parts of Europe, it has a place on the table as a fruit (fresh or pickled), in soft drinks and in the production of wines and liqueurs.

A bacterial leaf blight caused by Pseudomonas syringae has been observed in one nursery in Middle Tennessee. The location of the affected nursery was highly shaded, gorge-like valley and the environment appeared to be highly suited to the disease proliferation. The infected plants had blighted leaves and the young shoots had dark brown necrotic lesions and some had tip dieback (Fig. 1a). During the early stages of infection, leaves developed discrete lesions, angular in shape and surrounded by a chlorotic halo. These lesions eventually coalesced to form large dark necrotic patches that covered a large part or the entire leaf (Fig. 1b). Disease symptoms occurred only during the early spring when the weather was wet and cool. When the temperature increased, all new growths were symptomless (Mmbaga and Sheng, 1999; Mmbaga and Sheng, 2000).

Disease symptoms on C. mas were consistent with those caused by Pseudomonas syringae

\footnotetext{
Received for publication 28 Jan. 2006. Accepted for publication 4 Mar. 2006.

${ }^{1}$ To whom all correspondence should be directed;
} e-mailmmmbaga@tnstate.edu.
(Pscheidt et al., 2001; Sinclair and Backman, 1989; Sinclair et al., 1993) on other plants. The bacterium isolated from infected plants was identified as Pseudomonas syringae and fatty acid analysis showed that it was similar to P. syringae pv. maculicola (Mmbaga and Sheng, 1999, 2000). Bacterial pathogens that attack woody plants are known to survive on or within their hosts (Agrios, 1997). Bacterial infections occur through natural openings or wounds and free moisture on plant surfaces is critical during bacterial infection. Bacterial cells are transferred easily from plant to plant by handling or cutting instruments, water splash, and budwood (Agrios, 1997, Chase and Benson, 2001). Thus, cultural practices associated with plant production can affect disease development and spread.

Since the first report of this disease (Mmbaga and Sheng, 2000), some C. mas landscape plants displayed similar symptoms during early spring in 2000 and 2005, but the symptoms were insignificant. To date, this disease has remained destructive at only one nursery where it has become endemic. The objective of this study was to determine when disease developed naturally in the field and the conditions influencing disease development and evaluate bactericides and fungicides for controlling this disease.

\section{Materials and Methods}

Disease development and nursery environment: Disease developed naturally starting from a group of plants imported from Europe.

Fig. 1. Disease symptoms of bacterial leaf blight caused by Pseudomonas syringae. (a) Severely infected trees in the nursery field. (b) Disease progress on infected leaves.
Disease incidence was evaluated in the affected nursery for two growing seasons. Observations were made monthly from early May to July. Since the prevalence of this disease appeared during early spring, we suspected that cool temperature and moisture were important in disease development. Plant propagation from stem cuttings taken from apparently healthy branches of infected plants was observed and this practice may have perpetuated the disease at the nursery. A small study was conducted to evaluate whether the stem cuttings from healthy looking branches transmitted the disease to new plants. In 2000, 50 stem cuttings were taken from seemingly healthy branches of infected plants at the nursery field, 50 other cuttings were propagated from noninfected C. mas 'Redstone' plants grown at the University landscape evaluation plots. In 2002, additional 40 cuttings were taken from the propagated plants, 20 from each group. The new cuttings were rooted under mist in greenhouse environment at $25 \pm 3^{\circ} \mathrm{C}$ and they were monitored for disease symptoms during and after rooting.

Disease development was evaluated outside the nursery location using C. mas 'Redstone' plants inoculated with a field isolate of $P$. syringae from the nursery. The plants were grown in 3.75 -L plastic containers and maintained in a shade-house $(50 \%$ shade cloth) environment under drip irrigation. The bacterium was grown in nutrient agar and inoculum consisting of $10^{6}$ (colony forming units) $\mathrm{CFU} / \mathrm{ml}$ was prepared in sterile

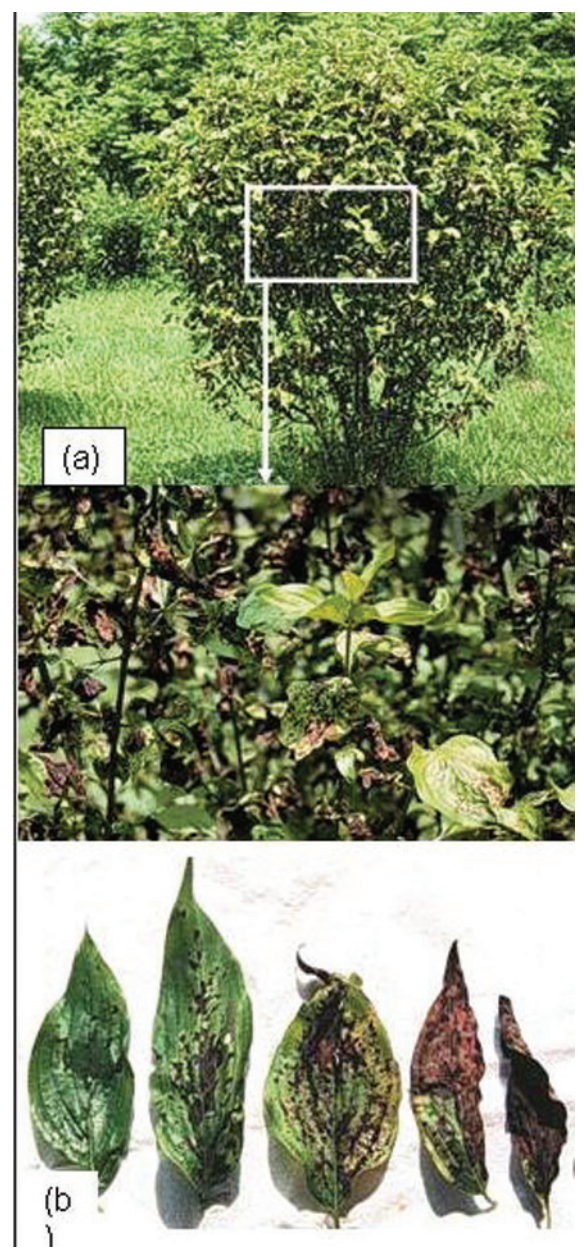


distilled water using 7-d-old cultures. Plants were sprayed to run-off using an atomizer to deliver inoculum uniformly. Inoculated plants were incubated for $24 \mathrm{~h}$ at $100 \% \mathrm{RH}$ and then placed back to drip irrigation. In 2004, plants were inoculated during the first week of May while in 2005 inoculation was done during the last week of April. Disease development was evaluated weekly using a scale of 0 to 5 in which $0=$ no infection, $1=1 \%$ to $10 \%, 2$ $=11 \%$ to $25 \%, 3=26 \%$ to $50 \%, 4=51 \%$ to $75 \%$, and $5=76$ to $100 \%$ of foliage showing disease symptoms. Temperature and precipitation were recorded daily.

Effect of temperature, leaf age, and leaf wounding on disease severity: This study was conducted using C. mas 'Redstone' grown in $10.3-\mathrm{cm}$ plastic containers and treatments consisted of four temperatures, two leaf ages (young and old), and leaf wounding (wounded and nonwounded). Four growth chambers (Percival Scientific Inc., Boone, Iowa) were set at four temperature regimes $[28 / 15,24 / 15$, $20 / 15$, and $15 / 10^{\circ} \mathrm{C}$ (day/night)] with $12 \mathrm{~h}$ day length. The experimental model used was a 4 $\times 2 \times 2$ factorial arrangement with a split plot experimental design and a replication of four individual plants per treatment. Noninoculated control was sprayed with water. Plants were separated by clear plastic walls designed to create small cubicles within each growth chamber. Young leaves were half expanded and mature leaves were fully expanded; half of each group of plants was wounded during inoculation and bacterial inoculum prepared as described above. Leaf wounding was done using multiple needles and the bacteria suspension was introduced into the plant by using a sponge/multiple needle inoculation method (Andrus, 1948). Plants in the nonwounded treatments were spray-inoculated using an atomizer to deliver the inoculum uniformly. Leaves were allowed to dry in open air (one hour) before the plants were incubated in a dew chamber at $20{ }^{\circ} \mathrm{C}$ and $100 \% \mathrm{RH}$ for $24 \mathrm{~h}$, and then moved to growth chambers set at 15/10, $20 / 15,24 / 20$ and $28 / 24^{\circ} \mathrm{C}$ (day/night) and $85 \%$ $\mathrm{RH}$. The study was repeated once.

Evaluation of pesticides for controlling bacterial blight. This 2-year study was conducted in shadehouse environment under $50 \%$ shade. Three-year-old plants (C. mas 'Redstone') were grown in 11.4-L plastic containers using Morton's Nursery Mix (Morton's Horticultural Supplies, Inc., McMinnville, Tenn.) consisting of $60 \%$ bark, $20 \%$ peat, and $20 \%$ sand. Starter fertilizer was applied in late April using $15 \mathrm{~N}-30 \mathrm{P}-15 \mathrm{~K}$ plant food (1 teaspoon/gal of water) and Osmocote controlled release fertilizer 14N-14PK applied in May at the rate of $50 \mathrm{~g} /$ container. All plants were watered daily by drip irrigation.

Six chemicals, Phyton-27 (copper sulfate), Camelot (copper salt of fatty acids), AgriMycin 17 (streptomycin), Kocide 101 (copper hydroxide), Basicop (elemental copper 53\%) and, Bordeaux mixture (cupric sulfate + lime) were evaluated using label recommended rates listed in Tables 2 and 3. Arandomized complete block design with a replication of five singleplants per treatment was used for experiment lay out. The study was initiated in early spring, soon after the last frost date. Plant foliage were spray-inoculated with a bacterial suspension of $10^{6} \mathrm{CFU} / \mathrm{mL}$ prepared as described above, noninoculated control was sprayed with water. The inoculated plants were incubated at $100 \% \mathrm{RH}$ for $24 \mathrm{~h}$ and monitored for disease symptoms. Chemical treatments were initiated when the inoculated plants started showing first disease symptoms.

Chemicals were applied using a $\mathrm{CO}_{2}$-pressurized sprayer with 12 psi pressure; all plants were sprayed to run off. The pesticides were reapplied at 10-d intervals until the end of June or early July when disease spread stopped and new leaves did not show disease symptoms. Disease severity was evaluated using the rating scale of 0 to 5 described above. All data were analyzed using General Linear Model Procedure for analysis of variance with chemical treatment as the treatment effect (Schlotzauer and Littell, 1987).

\section{Results}

Disease development and field nursery: When the disease was first observed, leaves were blighted with large reddish-brown to dark brown patches of dead tissue that covered most to the entire leaf(Fig. 1). Young twigs exhibited tip dieback and dark brown elongated lesions on the stems. The disease was restricted to early spring and the most severe infection started on the lower leaves, but within 2 weeks the whole tree got severely blighted; even young plants that were newly transplanted to the field were infected on the lower leaves. Disease spread stopped in mid to late June when new growth was disease-free. Over time, the new growth masked the infected leaves and improved plant appearance. The disease was not observed on any other potential hosts such as lilac, flowering pear or flowering dogwood that were grown at the nursery, but these potential hosts were not grown next to the $C$. mas plants.

Of 50 healthy-looking stem cuttings propagated from infected plants, 45 rooted. Of the 45 cuttings, 5 developed mild disease symptoms and $P$. syringae was isolated from the infected leaves. Similar number of cuttings from healthy plants rooted and none of them developed symptoms of bacterial blight. The greenhouse temperature was $25 \pm 3{ }^{\circ} \mathrm{C}$ during propagation, while the optimum temperature for this disease is 21 to $24^{\circ} \mathrm{C}$ with 10 to $15^{\circ} \mathrm{C}$ night temperature. In our study, all the propagated plants appeared to be disease-free in the following year and for an additional 3 years that they were maintained in the shade house. New plants propagated from these plants were also free of infection. Our results showed that the practice of taking stem cuttings from seemingly healthy branches of infected plants for propagation has the potential to transmit the pathogen to new plants.

Disease development under a shade house environment showed similar trend as observed in the field. Disease symptoms developed early in the season and disease severity increased rapidly during May and reached a plateau in early June. Disease severity began to decline in mid-June when new plant growth did not develop disease symptoms and the percentage of healthy tissueper plant continued to increase over time. Although the trend of disease development in 2004 and 2005 was similar, disease development started one week earlier and overall disease severity was higher in 2005 compared to 2004 (Fig. 2). The 1 -week delay in inoculation and subsequently delayed disease establishment may have caused the lower disease severity in 2004 compared to 2005 (Fig. 2). The temperature in May 2005 was cooler than in May 2004 and the total rainfall was higher in May 2005 (Figs. 3 and 4). Thus, the environment in 2005 was more favorable to the disease and may have contributed to the differences in disease severity in the 2 years.

Effect of temperature, leaf age, and leaf wounding on disease severity. Disease symptoms were most severe at $24 / 15^{\circ} \mathrm{C}$ followed by plants at $20 / 15^{\circ} \mathrm{C}$ (Table 1 ). Young leaves were highly susceptible to infection and they developed disease symptoms within $7 \mathrm{~d}$ and the wounded leaves developed symptoms in $5 \mathrm{~d}$. The nonwounded mature leaves were resistant to infection (Table 1). Mature leaves that had been wounded during inoculation developed a moderate level of infection at all temperatures.

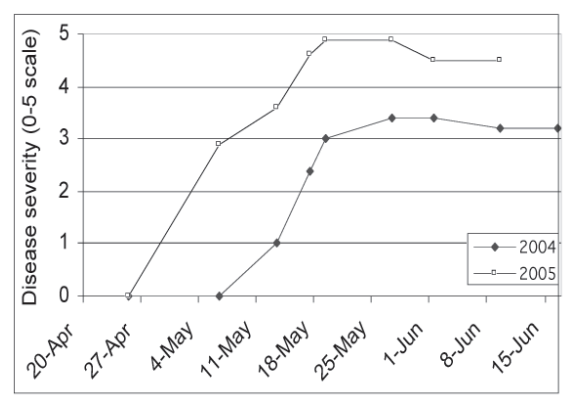

Fig. 2. Development of bacterial leaf blight in Cornus mas under $50 \%$ shadecloth. Disease severity was evaluated on a scale of 0 to 5 in which $0=$ no infection, $1=1 \%$ to $10 \%, 2=11 \%$ to $25 \%, 3=$ $26 \%$ to $50 \%, 4=51 \%$ to $75 \%$, and $5=76 \%$ to $100 \%$ of foliage showing disease symptoms.
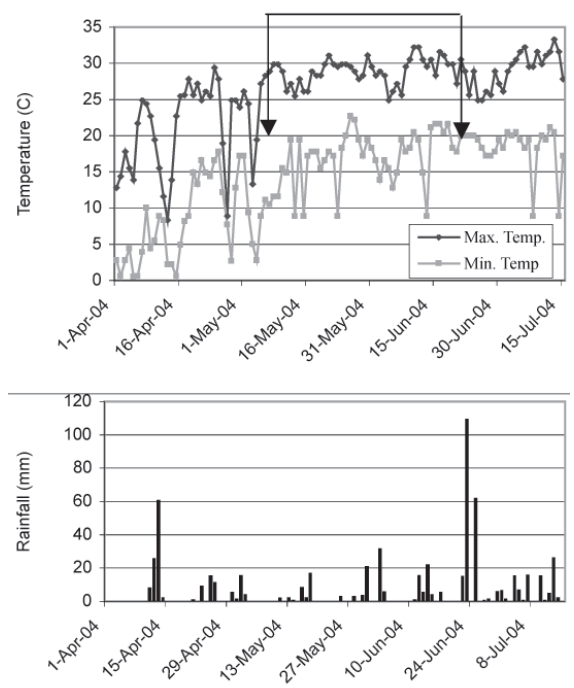

Fig. 3. Prevailing temperature and rainfall during Spring 2004 Pseudomonas syringae disease development in Cornus mas (arrows show the temperature during the period when disease developed and reached a plateau). 

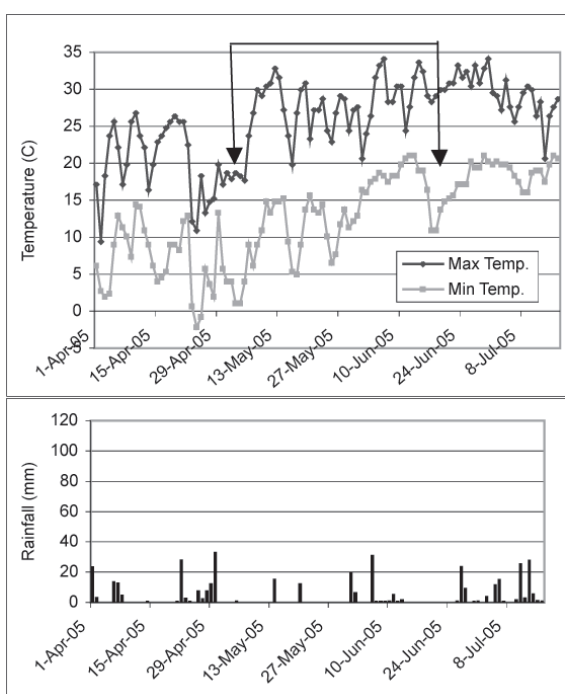

Fig. 4. Prevailing temperature and rainfall during Spring 2005 Pseudomonas syringae disease development in Cornus mas, (arrow shows the temperature during the period when disease developed and reached a plateau).

Although the higher temperature of 28/24 ${ }^{\circ} \mathrm{C}$ (day/night) was not favorable to disease development, wounding enhanced infection establishment; even in the mature leaves (Table 1). Similar results were obtained when the experiment was repeated.

Evaluation of pesticides for controlling bacterial blight. Expression of disease symptoms began $7 \mathrm{~d}$ after inoculation and disease severity in the nontreated plants increased rapidly during May and then stopped. In 2004, disease severity was moderately high, but in 2005 disease

Table 1. Effect of temperature, leaf age and leaf wounding on bacterial leaf blight disease severity in cornelian cherry dogwood (Cornus mas L.).

\begin{tabular}{lccccc}
\hline & \multicolumn{4}{c}{ Disease severity $^{z}$} \\
\cline { 2 - 3 } \cline { 5 - 6 } Temp & \multicolumn{2}{c}{ Young leaves } & & \multicolumn{2}{c}{ Mature leaves } \\
\cline { 2 - 3 } \cline { 5 - 6 }$\left({ }^{\circ} \mathrm{C}\right)$ & Spray inoculated & Wound inoculated & & Spray inoculated & Wound inoculated \\
\hline $28 / 15$ & $1.0 \mathrm{c}^{\mathrm{y}}$ & $4.5 \mathrm{a}$ & & $0.0 \mathrm{c}$ & $2.3 \mathrm{~b}$ \\
$24 / 15$ & $3.5 \mathrm{~b}$ & $4.7 \mathrm{a}$ & & $0.5 \mathrm{c}$ & $3.3 \mathrm{a}$ \\
$20 / 15$ & $3.0 \mathrm{~b}$ & $4.4 \mathrm{a}$ & & $1.5 \mathrm{a}$ & $3.3 \mathrm{a}$ \\
$15 / 10$ & $1.0 \mathrm{ab}$ & $2.5 \mathrm{~b}$ \\
\hline
\end{tabular}

${ }^{2}$ Disease severity on a 0 to 5 scale where $1=1 \%$ to $10 \%, 2=11 \%$ to $25 \%, 3=26 \%$ to $50 \%, 4=51 \%$ to $75 \%$, and $5=76 \%$ to $100 \%$ plant infection. Disease severity readings followed by same letters in the column are statistically similar.

${ }^{\mathrm{y}}$ Mean separation using least significant differences (LSD) at $p=0.05$ was calculated using general linear model procedure of SAS. When the study was repeated, similar results were obtained; data were combined for analysis.

Table 2. Effect of five fungicides and bactericides for control of bacteria blight of cornellian cherry dogwood (Cornus mas L.) in 2004.

\begin{tabular}{lccccc}
\hline & & \multicolumn{4}{c}{ Disease severity $(0-5 \text { scale })^{z}$} \\
\cline { 2 - 6 } Treatment & Rate/100 gal & 17 May & 27 May & 9 June & 16 June \\
\hline Phyton-27 & $3 \mathrm{fl} \mathrm{oz}$ & $0.8 \mathrm{a}^{\mathrm{y}}$ & $1.4 \mathrm{~b}$ & $1.2 \mathrm{a}$ & $1.2 \mathrm{a}$ \\
Agri-Mycin 17 & $3 \mathrm{pt}$ & $1.0 \mathrm{a}$ & $1.0 \mathrm{ab}$ & $1.0 \mathrm{a}$ & $1.0 \mathrm{a}$ \\
Bordeaux Mixture & $16 \mathrm{fl} \mathrm{oz}$ & $1.0 \mathrm{a}$ & $1.6 \mathrm{~b}$ & $1.8 \mathrm{a}$ & $1.6 \mathrm{ab}$ \\
Camelot & $1 \mathrm{lb}$ & $1.4 \mathrm{a}$ & $1.4 \mathrm{ab}$ & $1.8 \mathrm{a}$ & $1.8 \mathrm{ab}$ \\
Basicop & $2.5 \mathrm{lb}$ & $1.2 \mathrm{a}$ & $2.4 \mathrm{c}$ & $3.0 \mathrm{bc}$ & $3.0 \mathrm{bc}$ \\
Kocide 101 & $1 \mathrm{lb}$ & $3.0 \mathrm{c}$ & $3.0 \mathrm{~cd}$ & $3.25 \mathrm{c}$ & $3.25 \mathrm{c}$ \\
Nontreated control & & $2.4 \mathrm{~b}$ & $3.4 \mathrm{~d}$ & $3.2 \mathrm{c}$ & $3.2 \mathrm{c}$ \\
\hline
\end{tabular}

${ }^{2}$ Disease severity on a 0 to 5 scale where $1=1 \%$ to $10 \%, 2=11 \%$ to $25 \%, 3=26 \%$ to $50 \%, 4=51 \%$ to $75 \%$, and $5=76 \%$ to $100 \%$ plant infection. Disease severity readings followed by same letters in the column are statistically similar.

${ }^{y}$ Mean separation using least significant differences (LSD) at $p=0.05$ was calculated using general linear model procedure of SAS. plants as epiphytes. However, favorable environment allowed the infection to establish and proliferate within the nursery. It is reasonable to presume that the disease was perpetuated in the nursery partly by the cultural practice of plant propagation by stem cuttings from infected plants and by the favorable environment that kept the disease highly damaging.

Bacterial pathogens are known to survive on dormant buds and on infested leaf debris on the ground (Agrios, 1997; Pscheidt et al., 2001). In spring, rain splashes the bacterial cells to new tissue starting from the lower leaves; this was consistent with our observations on the most severe infection on the lower part of the plant. It is reasonable to presume that the cool and wet environment that persisted in early spring played an important role in the persistence and prevalence of the disease in the nursery. Stem lesions were not observed in shadehouse environment and infection with P. syringae was mostly on the leaves. Since C. mas shed its leaves at the end of the season, there was no source of inoculum in the following spring, thus, plants became disease free unless they were inoculated with the pathogen. However, infection in the field nursery included tip die-back and stem lesions and the pathogen may have survived on infected wood and some on infested leaves on the ground. Thus, the pathogen perpetuated to the following spring and bacterial cells could have been splashed onto the new foliage by spring rains.

Strains of $P$. syringae have been associated with tip die-back, leaf spots, leafblights, blossom blights and stem cankers in a large number of woody plants including cherry trees (Cameron, 1970; Latorre and Jones, 1979), poplar(DeKam, 1982; Sabet, 1953), lilac (Baca et al., 1987), rhododendron (Baca et al., 1987), flowering dogwood (Canfield et al., 1986), and aspen (Baca et al., 1987). In flowering dogwood, $P$. syringae was isolated from tip die-back and canker (Canfield et al., 1986) and the pathogen has previously caused severe damage in the northwestern region of the United States (Sinclair et al., 1993). However, when flowering dogwood plants were inoculated with the pathogen in growth chamber environment, disease symptoms did not develop (Mmbaga and Sheng, 1999). It is possible that the P. syringae strain isolated from C. mas (pv. maculicola) (Mmbaga and Sheng, 1999) may be different from that affecting these other $P$. syringae hosts at the nursery.

Some strains of $P$. syringae are known to form ice nucleus in some plant species resulting in frost injury at temperatures that would not normally cause frost damage in the absence of the bacteria (Pscheidt et al., 2001). Thus, severe damage associated with $P$. syringae in early spring may be associated with ice nucleation ability. For example, the severe damage of Aspen in the Pacific Northwest has been associated with its high susceptibility to $P$. syringae and ice nucleation ability (Baca et al., 1987). The strain of $P$. syringae from $C$. mas tested negative in ice nucleation tests (Mmbaga and Sheng, 1999).

Severe infections have been observed in only one nursery for 5 consecutive years and 
Table 3. Effect of five fungicides/bactericides for control of bacteria blight of cornellian cherry dogwood (Cornus mas L.) in 2005.

\begin{tabular}{|c|c|c|c|c|c|c|}
\hline \multirow[b]{2}{*}{ Treatment } & \multirow[b]{2}{*}{ Rate/100gal } & \multicolumn{5}{|c|}{ Disease severity $\left(0-5\right.$ scale $^{z}$} \\
\hline & & 6 May & 13 May & 19 May & 27 May 27 & 3 June \\
\hline Phyton-27 & $3 \mathrm{fl} \mathrm{oz}$ & $1.3 \mathrm{~b}^{\mathrm{y}}$ & $1.3 \mathrm{~b}$ & $1.6 \mathrm{~b}$ & $1.98 \mathrm{ab}$ & $1.4 \mathrm{a}$ \\
\hline Agri-Mycin 17 & $3 \mathrm{pt}$ & $1.3 \mathrm{~b}$ & $1.4 \mathrm{~b}$ & $1.1 \mathrm{a}$ & $1.4 \mathrm{ab}$ & $1.0 \mathrm{a}$ \\
\hline Bordeaux Mixture & $16 \mathrm{fl} \mathrm{oz}$ & $1.3 \mathrm{~b}$ & $1.6 \mathrm{~b}$ & $2.1 \mathrm{ab}$ & $1.9 \mathrm{bc}$ & $2.3 \mathrm{~b}$ \\
\hline Camelot & $1 \mathrm{lb}$ & $1.4 \mathrm{~b}$ & $2.0 \mathrm{c}$ & $2.4 \mathrm{~b}$ & $2.1 \mathrm{c}$ & $2.6 \mathrm{~b}$ \\
\hline Basicop & $2.5 \mathrm{lb}$ & $2.0 \mathrm{c}$ & $2.1 \mathrm{c}$ & $2.1 \mathrm{ab}$ & $2.3 \mathrm{c}$ & $2.9 \mathrm{~b}$ \\
\hline \multicolumn{2}{|c|}{ Nontreated control } & $2.9 \mathrm{~d}$ & $3.6 \mathrm{~d}$ & $4.6 \mathrm{c}$ & $4.9 \mathrm{~d}$ & $4.9 \mathrm{c}$ \\
\hline \multicolumn{2}{|c|}{ Noninoculated control } & $0.7 \mathrm{a}$ & $0.7 \mathrm{a}$ & $1.0 \mathrm{a}$ & $1.1 \mathrm{a}$ & $1.3 \mathrm{a}$ \\
\hline
\end{tabular}

${ }^{1}$ Disease severity ( 0 to 5 scale): $0=$ no infection, $1=1 \%$ to $10 \%, 2=11 \%$ to $25 \%, 3=26 \%$ to $50 \%, 4=$ $51 \%$ to $75 \%$, and $5=76 \%$ to $100 \%$ of the foliage showing disease symptoms.

${ }^{y}$ Means with the same letter in each column are not significantly different $(P=0.05)$. Mean separation using least significant differences (LSD) at $p=0.05$ was calculated by using general linear model procedure for analysis of variance by SAS.

the disease has not been reported elsewhere. Results from growth chamber experiments clearly showed that young succulent tissues were highly susceptible and the disease was favored by cool temperature of 20 to $24{ }^{\circ} \mathrm{C}$ with very cool nights of $15{ }^{\circ} \mathrm{C}$. Such cool nights are consistent with early spring weather in Tennessee. The increase in disease severity at cool temperatures $(24 / 15)$ may result from a combination of temperature and moisture effect. In cool nights, increased moisture on leaf surfaces resulting from dew formation would increase the period of leaf wetness and enhance infection establishment and subsequently disease severity (Burrage, 1969).

Therefore, the disease would be a problem limited to early spring when cool temperature is favorable and highly susceptible young plant tissue is available in abundance. The higher disease severity observed in May 2005 compared to that of 2004 (Fig. 2) may be attributed to the more favorable environment with overall cooler temperatures in 2005 compared to 2004 (Figs. 3 and 4). Although the heavy rainfall of 2005 may have favored the disease, the role of rainfall in disease severity was not clear in this study. Our results also showed that leaf wounding favored infection on mature leaves and at higher temperature of $28^{\circ} \mathrm{C}$. Thus, the use of Cornelian cherry as sheared hedge may require extra caution to avoid devastation from this disease.

Effective chemicals have been identified and Phyton 27 and Agri-Mycin were the two most effective chemicals in controlling the disease. The fungicides Camelot and Bordeaux
Mixture were effective when disease severity was moderate, but they were not effective when disease severity was high (Tables 1 and 2). Copper-based fungicides and bactericides have been reported to control bacterial blight in soybeans and beans (Sinclair et al., 1993, Schwartz and McMillian, 1989). Phyton 27 (Source Technology, Edina, Minn.) has been recommended for bacterial blight diseases, it is a relatively new broad spectrum fungicide/ bactericide labeled for ornamental crops. In this study, Phyton 27 worked as well as the bactericide Agri-Mycin. The copper-based fungicide Phyton 27 is also credited for having a curative property like the bactericide. However, none of the pesticides eliminated the disease all together; for effective disease control, the timing of pesticide applications needs to be initiated soon after budbreak when the first symptoms appear. An integrated disease management approach that combines different methods would be most effective. Propagation from noninfected plants would avoid the disease all together and use of other sanitary measures that target inoculum source from previously infected or infested material would also compliment disease control. Although effective pesticides have been identified, early application starting at bud break would be critical for effective control.

\section{Literature Cited}

Agrios, G.N. 1997.Plant pathology. 4th ed.Academic Press, New York.

Andrus, C.F. 1948. A method for testing beans for resistance to bacterial blights. Phytopathology
38:757-759.

Baca S, M.L. Canfield, and L.W. Moore. 1987. Variability in ice nucleation strains of Pseudomonas syringae isolated from diseased woody plants in Pacific Northwest nurseries. Plant Dis. 71(5):412-415.

Burrage, S.W. 1969. Dew and the growth of the uredospore germtube of Puccinia garaminis on wheat leaf. Ann. Appl. Biol. 64:495-501

Cameron, H.R. 1970. Pseudomonas content of cherry trees. Phytopathology 60:1343-1346.

Canfield, M.L., S. Baca, and L.W. Moore. 1986. Isolation of Pseudomonas syringae from 40 cultivars of diseased woody plants with tip dieback in Pacific Northwest nurseries. Plant Dis. 70: 647-650.

Chase, A.R. and M.D. Benson 2001. Bacteria, p. 25-26, In: R.K. Jones and M.D. Benson (eds.). Diseases of woody ornamentals and trees in nurseries. APS Press, St. Paul, Minn.

DeKam, M. 1982. Damage of poplar caused by Pseudomanas Syringae in combination with frost and fluctuating temperatures. Euro. J. For. Pathol. 12:203-209.

Dirr, M.A. 1990. Manual of woody landscape plants: Their identification, ornamental characteristics, culture, propagation and uses. Stipes Publ., Champaign, Ill.

Latorre, B.A. and A.L. Jones. 1979. Pseudomonas morsprunorum, the cause of canker in sour cherry in Michigan and its epiphytic association with $P$ syringae. Phytopathology 69:335-339.

Mmbaga, M.T. and H. Sheng. 1999. Leaf blight disease on Cornus mas. Proc. SNA Res. Conf. 44:265-269.

Mmbaga, M.T. and H. Sheng. 2000. The first report of leaf blight caused by Pseudomonas syringae on Cornus mas. Plant Dis. 84:200.

Pscheidt, J.N., L.W. Moore, and H.J. Scheek. 2001. Diseases caused by Pseudomonas syringae, $\mathrm{p}$. 59-62, In: R.K. Jones and M.D. Benson (eds.). Diseases of woody ornamentals and trees in nurseries. APS Press, St. Paul, MN.

Sabet, K.A. 1953. Studies on bacterial dieback and canker disease of poplar. III. Freezing in relation to the disease. Ann. Appl. Biol. 40:645-650.

Schwartz, H.F. and M.S. McMillian, 1989. Assaying bactericides efficiency against Pseudomonads on bean leaf surfaces. Plant Dis. 73:822-824.

Schlotzauer, S.D. and R.C Littell. 1987. SAS System for elementary statistical analysis. SFS Inst. Cary, N.C .

Sinclair, J.B. and P.A. Backman, 1989. Compendium of soybean diseases 3rd ed. APS Press, St. Paul, Minn.

Sinclair, W.A., H.H. Lyon, and W.T. Johnson. 1993. Diseases of trees and shrubs. 3rd ed. Cornell Univ. Press, Ithaca, N.Y. 